\title{
Universiteit
}

Leiden

The Netherlands

\section{An Alanic marginal note and the exact date of John II's battle with the Pechenegs}

Ivanov, S.A.; Lubotsky, A.M.

\section{Citation}

Ivanov, S. A., \& Lubotsky, A. M. (2011). An Alanic marginal note and the exact date of John II's battle with the Pechenegs. Byzantinische Zeitschrift, 103(2), 595-603. Retrieved from https://hdl.handle.net/1887/18310

Version: $\quad$ Not Applicable (or Unknown)

License: $\quad$ Leiden University Non-exclusive license

Downloaded from: $\quad$ https://hdl.handle.net/1887/18310

Note: To cite this publication please use the final published version (if applicable). 


\title{
AN ALANIC MARGINAL NOTE AND THE EXACT DATE OF JOHN II'S BATTLE WITH THE PECHENEGS
}

\author{
SERGEY A. IVANOV / MOSCOW AND ALEXANDR LUBOTSKY / LEIDEN
}

In 1992, while studying Byzantine liturgical manuscripts in the library of the Academy of Sciences in St. Petersburg, professor S. Engberg (Copenhagen) discovered some thirty marginal notes in the Greek manuscript Q12. ${ }^{1}$ The notes were written in Greek characters, but the language of the majority of them was not Greek, but Alanic, a pre-stage of Ossetic. ${ }^{2}$

The Petersburg manuscript is a Greek Old Testament lectionary, or Prophetologion, containing the Old Testament lections in the order in which they are read during the liturgical year. According to the

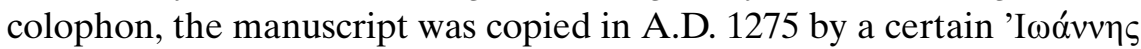
$\dot{\alpha} v \alpha \gamma v \omega \sigma \tau$ odiókovos (deacon responsible for the recital of the Holy Scripture in church) and at one point, maybe in the $14^{\text {th }}$ or even $15^{\text {th }}$ century, it was owned and used by an Alan who was supposedly entrusted with the recitation of the Holy Scripture in church and was sufficiently familiar with Greek to recite the readings, once he had located them in the manuscript. For this purpose, he wrote an abbreviated heading of his own in the margin, next to the full heading of the manuscript. ${ }^{3}$

On leaf 100r, the glossator provided the Greek heading $\tau \hat{n}$ $\pi \alpha \rho \alpha \mu \circ\left(v \underline{)} \tau \eta \hat{\varsigma} \varsigma \mu \varepsilon(\sigma o) v^{\prime}\right.$ (i.e. $\left.\mu \varepsilon \sigma o \pi \varepsilon v \tau \eta \kappa o \sigma \tau \eta ิ \varsigma\right)$, 'Eve of Mid-Pente-

The authors are indebted to O. Loseva, B. Lur'e and M. Želtov for their help.

1 For a description of the manuscript, see I. N. Lebedeva, Grečeskie rukopisi. Opisanie rukopisnogo otdela Biblioteki Akademii Nauk SSSR, 5. Leningrad 1973, 49.

2 For more details on the discovery and the manuscript itself see a preliminary report by S. Engberg/A. Lubotsky, Alanic marginal notes in a Byzantine manuscript: a preliminary report. Nartamonga: the Journal of Alano-Ossetic Studies 2 (2003 [2004]) 41-46, who are currently preparing an edition of the Alanic glosses.

3 We have no information on the provenance of the manuscript: the inventory of the Library (Index systematicus manuscriptorum in Bibliotheca Imperiali Academiae Scientiarum Petropolitanae. Sancta Petropolis, s. a., f. 4) only states that it was acquired in 1862. Yet, it can be surmised that the manuscript was sold to the Library by a Russian officer (or his family) who had participated in the Caucasus War and brought it as his booty (for a parallel see S. N. MaLaKHov, O grečeskoj pis'mennoj tradicii u narodov Severnogo Kavkaza v X-XVII vv. Mir pravoslavija. Volgograd 1997, 35-36). 


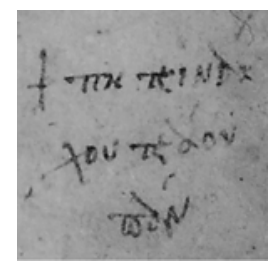

Q 12, leaf 100r, with an Alanic marginal note

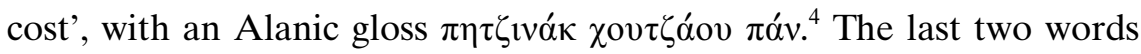

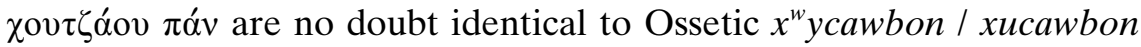
'Sunday', ${ }^{5}$ lit. 'day of the god', which is a calque of Greek кирıкк' $(\dot{\eta} \mu \varepsilon \hat{\varepsilon} \alpha)$. The development $a>o$ before nasals took place in Ossetic rather late, ${ }^{6}$ and in the $14^{\text {th }}$ or $15^{\text {th }}$ century, the word for 'day' must still have been ban in Alanic. This word is also found in an Alanic greeting

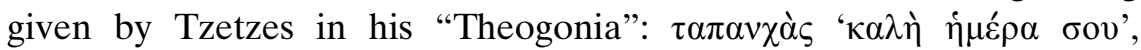
corresponding to modern Ossetic dae bon xorz / dae bon xwarz 'good day to you'. In the so-called "Yas word list" from the $15^{\text {th }}$ century, we encounter this greeting in the form daban horz. In Greek of this period, $\beta$ was a spirant $[\mathrm{v}]$, so that Alanic $[\mathrm{b}]$ was spelled with a $\pi$, not only in the marginalia, but also in the Zelenchuk inscription and in Tzetzes' "Theogonia". 8

The form $\pi \eta \tau \zeta$ เvók must stand for Alanic *bicincég and refer to the

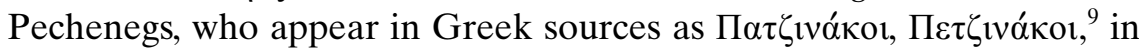

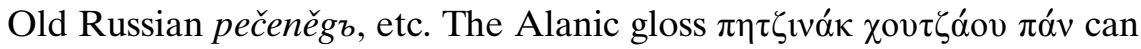
thus be rendered as 'Pecheneg Sunday'. What a kind of festival could it be?

4 This is the first edition of the 100r gloss.

5 When Ossetic forms are given, the first refers to the Iron (Eastern) dialect and the second to the Digoron (Western) dialect.

6 Cf. V.I. Abaev, Osetinskij jazyk i fol'klor, I. Moscow/Leningrad 1949, 256.

7 J. Németh, Eine Wörterliste der Jassen, der ungarländischen Alanen. Abhandlungen der deutschen Akademie der Wissenschaften zu Berlin. Klasse für Sprachen, Literatur und Kunst 1958/ 4. Berlin 1959, $14 \mathrm{f.}$

8 Cf. Abaev, Osetinskij jazyk (as footnote 6 above) $255 \mathrm{f}$. for a discussion.

9 For different spellings and variants of this ethnonym see Gy. Moravcsik, Byzantinoturcica II: Sprachreste der Türkvölker in den byzantinischen Quellen.

${ }^{3}$ Berlin 1983, $247 \mathrm{f}$. 
In the year 1121/1122, a group of Turkic tribes was driven out of Rus' by the prince Vladimir Monomakh. A Russian chronicle relates: "In the year 6629, Vladimir pushed out the Berendichs from Rus', whereas the Torks and the Pechenegs left on their own". ${ }^{10}$ According to Niketas Choniates, our main source on this subject, "in the fifth year" Byzantine emperor John II Comnenus' reign the nomads crossed the Danube and began plundering Thrace, "destroying everything under foot more absolutely than a host of locusts. John gathered the Roman forces, equipping them with the best arms possible, and marched against them, not only because of their great numbers, but also because of the arrogant behavior and grating boastfulness of these barbarians ... The emperor, first resorting to a stratagem, dispatched Patzinak-speaking envoys to attempt to persuade the enemy to agree to withdraw, if not all of them, then at least some, since they were divided into many tribes set up in separate field headquarters. Those chiefs he won over were greeted with every kindness. He set sumptuous feasts before them and charmed them with gifts of silk garments and silver cups and basins. While diverting the attention of the Patzinaks with such bait, he knew he must not delay in bringing his forces into battle array before the chiefs could make up their minds as to what course of action they should follow. They contemplated making peace with the Romans because of the promises made them, and, at the same time, they were confident that they would be victorious in battle, as they had always been in the past." 12

When did all these events take place? John II ascended to the throne on the $15^{\text {th }}$ of August, 1118. If we count from this date, his fifth year in power would last from the $15^{\text {th }}$ of August, 1122 until the $14^{\text {th }}$ of August, 1123. Yet, if Choniates counted from the beginning of the year, i.e. the $1^{\text {st }}$ of September, then the whole year of $1117-8$ would be the first regnal year of John II, although he actually held the reins only during the last two weeks of that year. This means that his fifth year would be from the $1^{\text {st }}$ of September, 1121 to the $31^{\text {st }}$ of August, 1122.

There are thus two possible dates for the Pecheneg incursion: 1123 or 1122. Both dates have their proponents. ${ }^{13}$ The former count looks more

10 Polnoe sobranie russkikh lětopisej II. Ipat'evskaja lětopis'. ${ }^{2}$ St. Petersburg 1908, col. 286.

11 Nicetae Choniatae Historia, ed. J. van Dieten. CFHB, 11. Berlin 1975, 13.39.

12 Ibid. 13.39-14.44; 14.48-61. The English translation is from H. J. Magoulias, O city of Byzantium. Annals of Niketas Choniates. Detroit 1984, 10.

13 Literature until the early $1980 \mathrm{~s}$ has been analyzed in M. V. BIBIKov, Vizantijskij istorik Ioann Kinnam o Rusi i narodakh Vostočnoj Evropy. Moscow 1997, $74-$ 
natural and is attested by many other Byzantine historians. ${ }^{14}$ The main argument in favor of 1122 is based on the following chain of propositions: 1) as follows from the Typikon of the Kosmosoteira monastery, Irene Dukaina, the mother of both John II and his brother Andronikos, died on the $19^{\text {th }}$ of February, most probably in $1123 ;{ }^{15} 2$ ) we know for sure that Andronikos died before her; ${ }^{16}$ 3) Andronikos participated in a war with a nomadic tribe living in wagons, most probably, the Pechenegs. ${ }^{17}$ Consequently, this war must have ended before 1123, which leaves us with the sole option of 1122. Nevertheless, many scholars insist on 1133 as the year of Irene Dukaina's death ${ }^{18}$ which leads them to dismiss the importance of the date of Andronikos' death $^{19}$ for the establishment of the date of the Pecheneg war. Yet, another argument for 1122 is the report of Michael the Syrian who dates this war to the year 1433 by the Seleukide era, which means 1121$1122 .^{20}$ The majority of historians tend to opt for 1122, but we would not exclude 1123 either.

Whatever the year, the Pecheneg war began in the fall and lasted until the spring. John Kinnamos, our second main source on this war, cites some details that are missing in Choniates: John II "as the winter overtook him there, passed the season someplace around the city of Beroia, partly to make ready for war, but more because he wished to win over some of their chieftains, so that when he had thus divided them, he could easily conquer the others. After he had by embassies induced many to come over to him, he advanced against the rest in

81. A more recent update is I. O. KNJAZ'KIJ, Vizantija i kočevniki južnorusskikh stepej. St. Petersburg 2000, 50-57.

14 For the events which are definitely dated by regnal years in cases in which such date contradicts "September years", cf. P. SchreINER (ed.), Die Byzantinischen Kleinchroniken, I. CFHB, 12/1. Wien 1975, 42.7; 230.11; Ioannis Scylitzae Synopsis historiarum, ed. I. Thurn. CFHB, 5. Berlin/New York 1973, 270.48; 276.23; 277.33; Michaelis Glycae Annales, ed. I. BEKKER. Bonn 1836, 502.9; 503.7; 504.4 .

15 D. Polemis, The Doukai: a contribution to Byzantine prosopography. London 1968, 7.

16 E. Kurtz, Unedierte Texte aus der Zeit des Kaisers Johannes Komnenos. BZ 16 (1907) 86, P. Gautier, L'obituaire du typikon du Pantokrator. REB 27 (1969) 250.

17 Bibikov, Vizantijskij istorik (as footnote 13 above) 76-78.

18 B. Skoulatos, Les personages byzantins de l'Alexiade. Louvain 1980, 124.

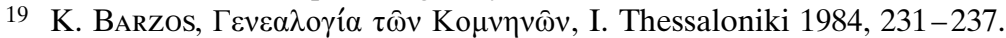

20 Chronique de Michel le Syrien, ed. J.-B. Снавот, III. Paris 1905, 206. Cf. F. Chalandon, Jean II Comnène et Manuel I Comnène. Paris 1912, 48-51. 
spring, wishing to decide matters by battle". ${ }^{21}$ Consequently, the decisive battle took place near Beroea, today's Stara Zagora, in the spring of 1122 or 1123 .

According to Choniates, "John engaged the Patzinaks in combat in the morning twilight, and there ensued one of the most frightful and terrifying battles ever fought. The Patzinaks met our troops bravely, making resistance difficult with their cavalry charges, discharge of missiles, and war cries. Once the Romans had joined in battle, they were committed to fighting to the death or to the victory. The emperor, escorted by his companions and bodyguards, provided assistance all the while to his beleaguered troops. In the thick of battle the Patzinaks ... frustrated the Roman assault. ... John ... routed the Patzinak battalions just as Moses had turned back the troops of Amalek ... Taking with him his bodyguards, ... John went forth like an unbreakable wall to meet the Patzinaks... The enemy was put to inglorious flight, and the Romans pursued them boldly. The wagon folk fell by the thousands ..., the captives were beyond number". ${ }^{22}$ Kinnamos informs us that "when the armies clashed with one another, the battle was for some while in balance and then the emperor himself was hit in the leg by an arrow. But since the Romans fought courageously, the Pechenegs were severely defeated, some of them fell". Yet, it was not the victory still: the nomads retreated to their camp and resisted all the assaults of the Byzantines. "So again a fierce battle occurred and a slaughter ensued on both sides. The Pechenegs treated the carts like a fortress and wrought great harm to the Romans ... The emperor ... ordered the ax-bearers around him ... to cut apart with their axes the opposing [wagons] ... The emperor thus became master of the Pechenegs' camp". So, finally, it was the Varangian guard of the emperor which won the day. The Pechenegs were defeated completely and disintegrated as a political entity forever.

The victory was widely celebrated. ${ }^{23}$ Niketas Choniates sums up his narration on the Pecheneg war by saying that the Emperor John II "having achieved such a glorious victory over the Patzinaks, raised a huge trophy and offered prayers to God and, as a remembrance and

21 Ioannis Cinnami Epitome, ed. A. MeIneke. Bonn 1836, 7.17-22. The English translation is from Ch. Brand, John Kinnamos. Deeds of John and Manuel Comnenus. New York 1976, 16.

22 Nicetae Choniatae Historia (as footnote 11 above) 14.62-16.10; cf. Magoulias (as footnote 11 above) 10-11; Ioannis Cinnami Epitome (as footnote 21 above) $7.22-8.22$.

23 P. Georgiev, Za značenieto na nadpisa ot 1142 g. v Pliska. Minalo 2002/2, 15. 
thanksgiving for these deeds, established what we today call the festival of the Patzinaks". ${ }^{24}$

And now we finally turn to the actual festival, mentioned in our Alanic marginal note. Although this festival is sometimes mentioned in historical studies, ${ }^{25}$ it has never been noticed that besides Choniates, there exists another Byzantine source indicating its reality: the juridical commentary Ecloga basilicorum, written before $1142,{ }^{26}$ states that one may appeal a court verdict in a higher court within ten days after the sentence; yet, "days of rest are not counted, neither are the holidays which were not proclaimed from the very beginning, but promulgated as resting days later, because a victory happened on this day, for example,

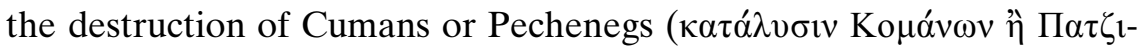
vók $\omega v) "{ }^{27}$ It seems unlikely that there were two different holidays - one celebrating the victory over the Cumans and another over the Pechenegs. Rather, by naming the festival in this way the Byzantine commentator corroborates the view shared by modern historians that the horde which was defeated in 1122-1123 consisted not only of Pechenegs, but also of Cumans, also known as Polovtses. ${ }^{28}$ Moreover, this war was called a "Cuman war" by Michael the Syrian's Chronicle, ${ }^{29}$ a source which was not constrained by the Byzantine ideological clichés.

The Greek and the Scandinavian sources ${ }^{30}$ contain no indication as to when exactly the battle with the Pechenegs took place, nor when the holiday was celebrated. We have already stated that the Alanic marginal note 'Pecheneg Sunday' is written in our manuscript Q12 near the Greek heading 'Eve of Mid-Pentecost', which at first sight may appear strange: Mid-Pentecost is not a Sunday, but a Wednesday. On the other hand, it is not unusual that a festive event is celebrated not on its exact date, but in accordance with the place this day occupies in the liturgical calendar. Sometimes a feast was connected to the Sunday closest to it:

24 Nicetae Choniatae Historia (as footnote 11 above) 16.11-14. The translation is from Magoulias 11.

25 Cf., for instance, F. Curta/P. Stephenson, Southeastern Europe in the Middle Ages, 500-1250. Cambridge 2006, 312-314.

26 Ecloga Basilicorum, hrsg. L. Burgmann. Forschungen zur Byzantinischen Rechtsgeschichte, 15. Frankfurt am Main 1988, XVII.

27 Ibid. 332.22-25.

28 Biвikov, Vizantijskij istorik (as footnote 13 above) 85-89.

29 Chronique de Michel le Syrien (as footnote 20 above) 206.

30 For which see, for instance, J.R. Hagland, Slaget på Pezinavellir i nordisk og bysantinsk tradisjon. Scripta Islandica. Isländska sällskapets årsbok 41 (1990 [1991]) 3-17. 
this happened with the commemoration of ashes that fell on Constantinople after the Vesuvio eruption of the $6^{\text {th }}$ of November, $472-$ the event was celebrated every year on the Sunday before $6^{\text {th }}$ of November. ${ }^{31}$ During the Triodion period, movable feasts gained undisputed prominence over immobile dates. Thus, the commemoration of the "Six Oecumenical Councils" was celebrated on the Sunday before Pentecost ${ }^{32}$ and initially marked the exact date of the Church Council of 536; the same happened to the feast of the Adoration of the Cross, which is now celebrated in the middle of Lent, but initially marked the victory of the Emperor Heraclius over Persians in 628. Two earthquakes were celebrated the next day after Pentecost ${ }^{33}$ and the fourth day after Palm Sunday. ${ }^{34}$

It is therefore not at all striking that the Pecheneg victory was hooked on to the movable feast of Mid-Pentecost, but the problem is that the battle can hardly have taken place on the Sunday of the MidPentecost week, or, for that matter, on the exact date of Mid-Pentecost. Ecloga Basilicorum insists that this day must be considered a rest day, which means that before the battle it was a regular working day. Meanwhile, Mid-Pentecost was an official holiday anyway. The edict of the Emperor Manuel I Comnenus, the son of John II, unequivocally proclaimed: "Together with these days, also the mid-way points of ... Pentecost will be included as full holidays". ${ }^{35}$ As for Sundays, they have always been days of rest. ${ }^{36}$ We should consequently assume that the Pecheneg victory fell on one of the regular working days of the MidPentecost week and only later was transferred to the Sunday of that week.

Due to the Alanic gloss, we are now in a position to further specify the date of the historic battle against the Pechenegs in 1122 or 1123. In the year 1122, Easter fell on the $26^{\text {th }}$ of March,$^{37}$ which means that MidPentecost was Wednesday, the $19^{\text {th }}$ of April. ${ }^{38}$ The battle of Beroea in

31 J. Mateos, Le Typicon de la Grande Église, I: Le cycle des douze mois. Orientalia Christiana Analecta, 165. Roma 1962, 90.

32 J. Mateos, Le Typicon de la Grande Église, II: Le cycle des fêtes mobiles. Orientalia Christiana Analecta, 166. Roma 1963, 130.

33 Ibid., 140.

34 Ibid., 58.

35 R. J. MACrides, Justice under Manuel I Komnenos: Four novels on court business and murder. Fontes Minores, 6. Frankfurt am Main 1984, 150.

36 Basilica 7, 17, 19.

37 V. Grumel, La chronologie. Paris 1958, 310.

38 Ibid. 313. 
such case took place either on the $20^{\text {th }}-22^{\text {nd }}$ or on the $24^{\text {th }}-26^{\text {th }}$ of April. If the battle was fought in 1123, then Easter fell on the $15^{\text {th }}$ of April and Mid-Pentecost on the $9^{\text {th }}$ of May. The day of the victory could then be either the $10^{\text {th }}-12^{\text {th }}$ or the $14^{\text {th }}-16^{\text {th }}$ of May. ${ }^{39}$

The final question to be asked is: how and when did the Alans get acquainted with the Pecheneg Festival? Nicetas Choniates was writing about it in the closing years of the $12^{\text {th }}$ century, but the Alans could acquire it from the Byzantine clerics even earlier. This century was a heyday for the Orthodox Christianity in the Northern Caucasus. ${ }^{40}$ It was the time when Greek inscriptions were fairly frequent ${ }^{41}$ and when the Greek alphabet started to be used for writing the indigenous languages. ${ }^{42}$ We do not know for how long the victory over the Pechenegs was commemorated in Byzantium proper, since in a distant region such as Alania it could get petrified for centuries. ${ }^{43}$

39 One anonymous reviewer of the present article suggests that probably Choniates was wrong in attributing the Pecheneg festival to the battle of Beroea - he/she hypothesizes that it could be promulgated after the battle of Levounion in 1091. "I stress the battle of Lebunion (and Anna Komnene's account) especially because it took place on Tuesday, April the 29th 1091: according to Grumel's Chronology Easter in 1091 fell on April the 13th, the day of Mid-Pentecost would then have been May the 7th, Wednesday. The 'Pecheneg Sunday', according to the author's arguments could have consequently been both May the 11th, and May the 4, the first Sunday after the day of the battle of Lebunion." We cannot agree with this standpoint. It is true that Choniates wrote many years after the event, but so did Anna as well. On the other hand, had this festival been promulgated by Alexius, Anna would not have missed the chance to mention it.

40 S. A. Ivanov, Vizantijskoe missionerstvo. Moscow 2003, 253-26; idem, Religious missions, in J. ShePard (ed.), The Cambridge History of the Byzantine Empire. Cambridge 2008, 329-330.

41 Cf. I. Pomjalovskis, Sbornik grečeskikh i latinskikh nadpisej Kavkaza. St. Petersburg 1881, 12; V. A. KuZnetsov, Arkheologičeskie razvedki v Zelenčukskom rajone Stavropol'skogo kraja v 1953 godu. Materialy po izučeniju Stavropol'skogo kraja, 6. Stavropol' 1954, 351; M. N. LožKıN, O vnov' otkrytykh pamjatnikakh èpigrafiki domongol'skogo vremeni v verkhov'jakh Kubani. $X$ "Krupnovskie čtenija” po arkheologii Severnogo Kavkaza. Sbornik tezisov. Moscow 1980, 59-61; V.I. JAJLEnKo, O "Korpuse vizantijskikh nadpisej v SSSR". $V V 48$ (1987) 169.

42 For instance, the Kabardian Etoka inscription (G.F. TuRČAnINOv, Epigrafičeskie zametki. Izvestija Akademii Nauk. Otdelenie literatury i jazyka 6/6 (1947) 512515) and the famous Old Ossetic or Alanic Zelenchuk inscription (L. ZGUSTA, The Old Ossetic inscription from the river Zelenčuk. Wien 1987, 59).

43 For example, the tradition of writing in Greek in the Northern Caucasus outlived Byzantium: the last Greek inscription in Western Cherkessia is dated by 1557, in Eastern Cherkessia by 1623, cf. MaLaKhov, O grečeskoj pis'mennoj tradicii (as footnote 3 above) 36 . 
The Ossetic expression for 'to strive, hanker, yearn for something' is byc'ynag sk ${ }^{\text {ww }}$ nyn / bic'inag sk'unun ${ }^{44}$ which literally means something like 'to exterminate the Pechenegs'. ${ }^{45}$ The idiom seems to indicate that the Alans severely suffered from this steppe people in the past, so that it becomes understandable why they kept celebrating the Pecheneg Festival long after the Pechenegs themselves had disappeared from their horizon.

\begin{abstract}
The Greek Prophetologion manuscript Q12 from the library of the Academy of Sciences in St. Petersburg, copied in 1275, contains some thirty marginal notes written in Alanic, a pre-stage of Ossetic.

On leaf 100r, the glossator provided the Greek heading $\tau \hat{n} \pi \alpha \rho \alpha \mu \mathrm{o}(v \underline{\text { nิ }}) \tau \hat{\eta} \varsigma$

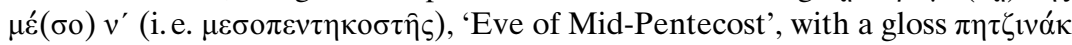

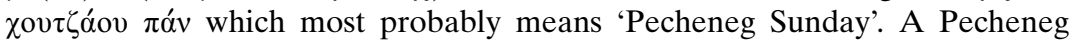
festival established after the decisive victory of John II over the Pechenegs is attested by both Nicetas Choniates and Ecloga Basilicorum. It is no wonder that this festival reached distant Alania, since the 12th century was a heyday for the Orthodox Christianity in the Northern Caucasus.

The battle took place near Beroea in spring of the "fifth year" of John II's reign. The majority of historians tend to opt for 1122, but we would not exclude 1123 either. Whatever the year, the marginal note from Q12 may help in establishing the day of the battle, which is not mentioned either in Greek or in Scandinavian sources. If the battle of Beroea took place in 1122, it happened either on the 20th-22nd or on the 24th-26th of April. If the battle was fought in 1123 , the day of the victory could then be either the 10th-12th or the 14th-16th of May.
\end{abstract}

44 V. F. Miller, Osetinsko-russko-nemeckij slovar'. Pod redakciej i s dopolnenijami A. A. Frejmana. Leningrad1927, 373: byc'ynaeg sk'unyn / bic'inag sk'unun “poryvat'sja, strastno stremit'sja, starat'sja; sich reißen - sehnen - bemühen”. The verb $s k^{, w} y n y n / s k$ 'unun means 'to tear up, exterminate'. 